\title{
Properties of a thick-section narrow-gap gas tungsten arc weld of cast Haynes 282
}

\author{
Michael Santella ${ }^{1}$ (D) X. Frank Chen ${ }^{1}$ (I) $\cdot$ Philip Maziasz $^{1} \cdot$ Jason Rausch $^{2} \cdot$ Jonathan Salkin $^{2}$ \\ Received: 12 November 2020 / Accepted: 19 January 2021 / Published online: 28 January 2021 \\ (C) The Author(s) 2021
}

\begin{abstract}
A 50.8-mm-deep gas tungsten arc weld was made with matching filler metal in cast Haynes 282 alloy. The narrow-gap joint was filled with 104 weld beads. Visual and dye-penetrant inspection of cross-weld specimens indicated that the cast base metal contained numerous casting defects. No visible indications of physical defects were found in the weld deposit. The weld heataffected zone was characterized by microcracking and localized recrystallization. The cause of the cracking could not be determined. Hardness testing showed that a softened region in the as-welded heat-affected zone was nearly eliminated by post-weld heat treatment. Tensile testing up to $816^{\circ} \mathrm{C}$ showed that cross-weld specimen strengths ranged from 57 to $79 \%$ of the cast base metal tensile strength. The stress-rupture strengths of cross-weld specimens are within $20 \%$ of base metal reference data. Failures of both tensile and stress-rupture specimens occurred in the base metal.
\end{abstract}

Keywords Haynes $\cdot 282 \cdot$ UNS N07208 $\cdot$ Strength $\cdot$ Hardness $\cdot$ Weld $\cdot$ Cast

\section{Introduction}

There are interests in the utility power generation industry for increasing thermodynamic efficiencies and reducing environmental impacts by increasing the operating temperatures and pressures of various energy conversion systems. An important element of this overall strategy will depend on the availability or development of higher temperature alloys than are typically used in more conventional systems. [1-3] Critical components such as heavy-wall pipe and headers, tubing, and large landbased turbine parts will require the use of nickel-based alloys with good high-temperature strength and fabricability. An alloy that has emerged as a candidate for some of these applications is Haynes 282 (UNS N07208, Haynes and 282 are registered trademarks of Haynes International). [4, 5] Although Haynes 282 was originally targeted for applications

Recommended for publication by Commission IX - Behaviour of Metals Subjected to Welding

Michael Santella

mlsantella@gmail.com

1 Oak Ridge National Laboratory, Oak Ridge, TN, USA

2 Arc Applications, Inc., York, PA, USA where it would be used in thinner gages, $[6,7]$ it is also being evaluated for thick-walled wrought and cast applications.

The primary objective of the work presented here was to make a thick-section weld and assess its stress-rupture properties. This was done by making a 50.8 -mm-deep narrow-gap gas tungsten arc weld in a section of a Haynes 282 casting.

\section{Materials and methods}

The base metal used for this weld was taken from a hollow cylindrical ring section cut from a large, prototype valve body casting weighing approximately $7700 \mathrm{~kg}$. [5] The size of the ring was approximately $355-\mathrm{mm}$ OD $\times 100$-mm wall $\times 152$ $\mathrm{mm}$ ring height. The ring section was homogenized, spending $68 \mathrm{~h}$ between 1190 and $1225^{\circ} \mathrm{C}$, and given the recommended two-step strengthening heat treatment of $2 \mathrm{~h}$ at $1010{ }^{\circ} \mathrm{C}$ followed by $8 \mathrm{~h}$ at $788^{\circ} \mathrm{C}$. [8] Because extensive machining was required to prepare the joint for welding, [9] the cast metal was given another solution heat treatment of $1 \mathrm{~h}$ at $1150^{\circ} \mathrm{C}$ to reduce its hardness. Eventually, a narrow-gap joint, 17.8-mmwide $\times 50.8$-mm-deep, was set-up for welding. The joint dimensions are shown in Fig. 1.

The welding was done with the gas tungsten arc (GTA) welding process using an AMI 415 welding power supply in 
Fig. 1 Drawing of narrow-gap joint with dimensions in $\mathrm{mm}$

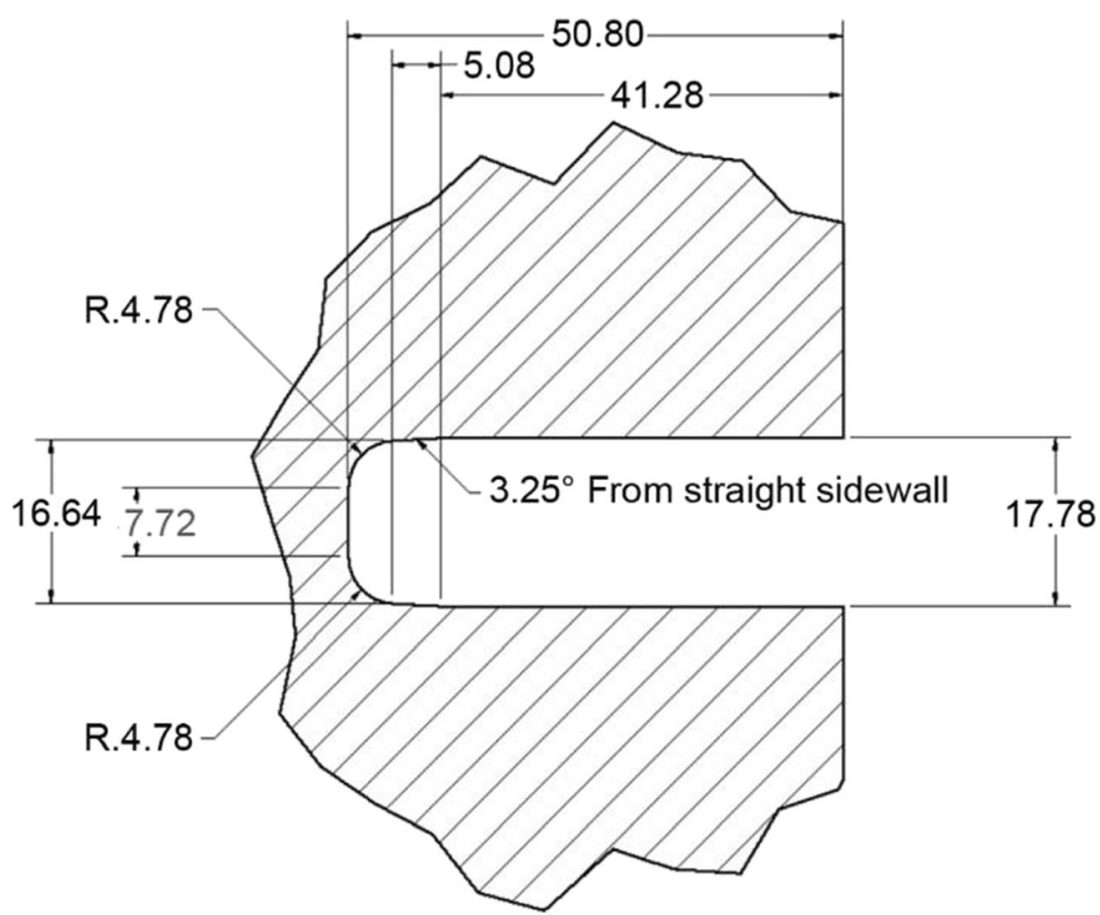

conjunction with an AMI Model 52 weld head that was equipped with an AMI NGT-B torch (Arc Machines, Inc. https://www.esabna.com). The travel motion was provided by a Pandjiris positioner (Pandjiris Inc., www.pandjiris.com) controlled by an AMET controller (Advanced Manufacturing Engineering Technologies, www.ametinc.com). The welding torch was positioned at top dead center of the joint in the flat welding position. The torch remained at that position throughout welding as the joint assembly was rotated beneath it.

Filler metal was supplied to the torch using cold wire feed with spooled, 1.14-mm-diameter Haynes 282 wire. The arc shielding gas was a mixture of $50 \% \mathrm{Ar}+50 \% \mathrm{He}$. In an effort to provide better shielding during the welding, auxiliary shielding with $100 \%$ Ar was also supplied using a shroud constructed to match the OD curve of the joint. Slots were made in the shroud to allow for the wire guide conduit to pass through it. Extensions were added to both the start and end of the weld groove to help maintain good shielding. The start and stop ends of the weld were located at the extremities of the joint groove. This produced a weld length of about $550 \mathrm{~mm}$ at the depth of the weld joint root.

The weld was completed with 104 welding passes using a 3-mm-diameter W-1.5\% La electrode in the GTA torch. Welding passes 1-4 used a primary current of 240 A, a background current of $140 \mathrm{~A}, 11 \mathrm{~V}$, and wire feed speed of 14.8 $\mathrm{mm} / \mathrm{s}$. Afterwards, the primary current was increased to 250 $\mathrm{A}$, the background current was increased to $150 \mathrm{~A}$, arc voltage was decreased to $10.9 \mathrm{~V}$, and wire feed was increased to 21.2 $\mathrm{mm} / \mathrm{s}$. Arc travel speed was maintained at $2.1 \mathrm{~mm} / \mathrm{s}$ throughout the welding. No preheating was used and interpass temperatures ranged between 24 and $103{ }^{\circ} \mathrm{C}$. [9]

During welding, base metal cracks in the joint groove sidewalls were observed at various locations but the weld was completed to its full 50-mm thickness. Dye-penetrant inspection showed numerous defect indications in the base metal of the completed weld but no defects were observed in the weld deposit. [9] After the weldment was detached from the fixturing, 6 6.35-mm-thick cross-weld slices were removed by electrical discharge machining (EDM) to supply material for metallographic analyses and hardness testing. The slices were located near the stop and start ends of the weld, in the approximate mid-length of the weld, and one at about $150 \mathrm{~mm}$ from its end point. [9] The machined surface of one slice is shown as Fig. 2 where a number of shrinkage defects are visible in the base metal. Visual examination of the slices suggested the weld deposit at this location was free of defects. The completed weld was not subjected to any other nondestructive evaluations such as radiography. One cross-weld slice was kept in the as-welded condition. A second slice was given a final strengthening heat treatment of $2 \mathrm{~h}$ at 1010 ${ }^{\circ} \mathrm{C}$ followed by $8 \mathrm{~h}$ at $788^{\circ} \mathrm{C}$. Also, 30 cross-weld cylindrical rod blanks were removed from the weld by EDM and given the same final heat treatment. [9]

Specimens for both optical and scanning electron metallographic examinations and hardness testing were mounted in epoxy and polished on a Struers TegraForce-5/TegraPol-31 polishing system (www.struers.com) using Struers polishing cloths and consumable abrasives. Final polishing was done with a $0.5-\mu \mathrm{m}$ diamond suspension. Etching was done with 


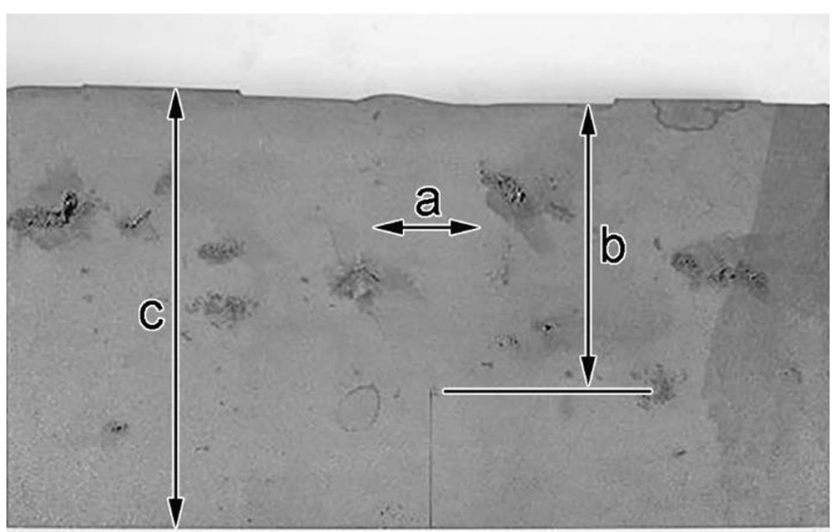

Fig. 2 Photograph of an EDM-cut cross-weld slice showing:(a) the approximate weld width of $18 \mathrm{~mm}$, (b) the approximate weld depth of 50 $\mathrm{mm}$, and (c) the approximate EDM cut depth of $75 \mathrm{~mm}$. The dark features are associated with shrinkage defects in the cast base metal and bleed-out of cutting/cleaning fluids

a solution of $20 \mathrm{ml}$ glycerol $+30 \mathrm{ml} \mathrm{HCl}+20 \mathrm{ml} \mathrm{HNO}_{3}$. The scanning electron microscope (SEM) was a Hitachi S-4800 with a field emission gun. The SEM was also fitted with an EDAX energy dispersive X-ray (EDS) system and a YAG backscattered detector.

The heat-treated cross-weld cylindrical rod blanks were machined into cross-weld test specimens having reducedsection gage dimensions of $57.15-\mathrm{mm}$ length $\times 6.35-\mathrm{mm}$ diameter. The approximately 18 -mm-wide weld deposit was centered in the specimen gage lengths. The specimen design was consistent with the small-size specimen dimensions specified by ASTM E8. After machining, the general condition of the specimens was assessed by dye-penetrant inspection. No defect indications were found in the weld deposit portions of the specimen gage lengths. Specimens with visible defect indications of $0-0.4 \mathrm{~mm}$ maximum in the base metal portions of the gage lengths were used for initial tensile and stress-rupture testing. The remainder of the specimens was held in reserve.

\section{Results and discussion}

Chemical analysis results for the cast base metal, the weld wire, and a specimen cut from the weld deposit are provided in Table 1 where they are compared to the UNS N07208 chemistry specification.

\subsection{Microstructures}

\subsubsection{Base metal}

The cast base metal microstructure was characterized by a large average grain size. Grain size was not measured, but
Table 1 Chemical analysis results in wt $\%$ with Ni balance

\begin{tabular}{lllll}
\hline Element & Base metal $^{1}$ & Weld wire $^{2}$ & Weld deposit $^{1}$ & UNS N07208 \\
\hline $\mathrm{Al}$ & 1.44 & 1.43 & 1.54 & $1.38-1.65$ \\
$\mathrm{~B}$ & 0.008 & 0.004 & 0.003 & $0.003-0.010$ \\
$\mathrm{C}$ & 0.07 & 0.060 & 0.05 & $0.04-0.08$ \\
$\mathrm{Co}$ & 10.06 & 10.17 & 10.20 & $9.0-11.0$ \\
$\mathrm{Cr}$ & 19.20 & 19.39 & 19.28 & $18.5-20.5$ \\
$\mathrm{Cu}$ & 0.01 & 0.01 & 0.01 & $0.1 \max$ \\
$\mathrm{Fe}$ & 0.46 & 0.84 & 0.75 & $1.5 \max$ \\
$\mathrm{Mn}$ & 0.04 & 0.07 & 0.06 & $0.3 \max$ \\
$\mathrm{Mo}$ & 8.28 & 8.63 & 8.41 & $8.0-9.0$ \\
$\mathrm{Nb}$ & 0.05 & $<0.1$ & 0.04 & $0.2 \max$ \\
$\mathrm{P}$ & 0.004 & 0.002 & 0.005 & $0.015 \max$ \\
$\mathrm{S}$ & 0.002 & $<0.002$ & 0.001 & $0.015 \max$ \\
$\mathrm{Si}$ & 0.17 & $<0.05$ & 0.07 & $0.15 \max$ \\
$\mathrm{Ti}$ & 2.31 & 2.21 & 2.14 & $1.90-2.30$ \\
$\mathrm{Zr}$ & 0.01 & $<0.002$ & $<0.01$ & $0.020 \max$ \\
$\mathrm{O}$ & $<0.01$ & --- & 0.01 & --- \\
$\mathrm{N}$ & 0.01 & --- & 0.01 & --- \\
\hline
\end{tabular}

${ }^{1}$ Optical emission spectroscopy, except $\mathrm{O}$ by inert gas fusion-infrared absorbance, and $\mathrm{N}$ by inert gas fusion-thermal conductivity (IMR Test Labs, www.imrportland.com)

${ }^{2}$ Haynes Wire Co. product certification

individual grains exceeding several millimeters in their largest dimension were visible on smooth, cut, or machined surfaces without the aid of magnification. Large second-phase particles mainly precipitated on grain boundaries were found throughout the base metal (Fig. 3). Microchemical analysis with EDS in the SEM was supplemented with thermodynamic calculations (JMatPro, Ni database version 6, sentesoftware.co.uk) to indicate that most of the grain boundary particles were MC

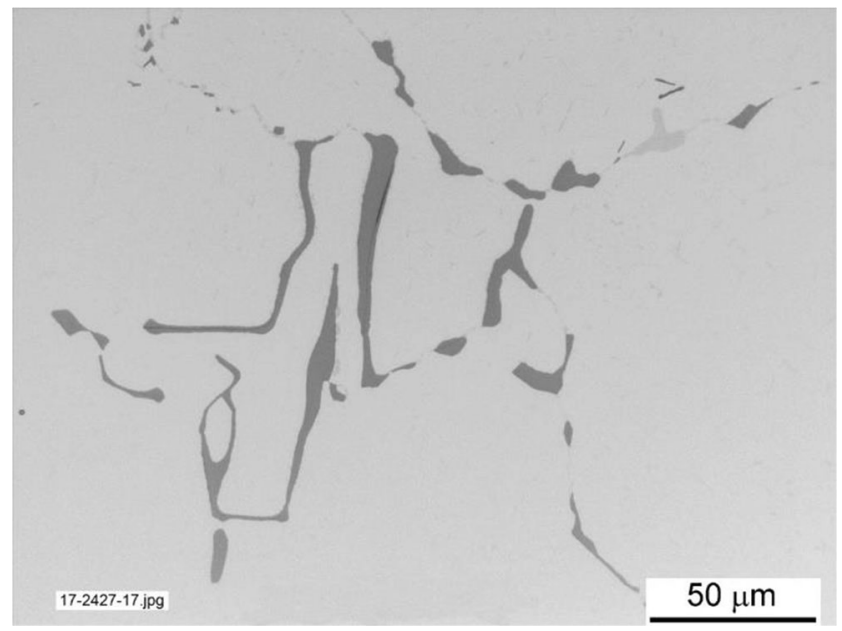

Fig. 3 Optical micrograph showing general features of cast microstructure after post-weld strengthening heat treatment 
phases of variable chemical composition, mainly containing $\mathrm{Mo}, \mathrm{Ti}, \mathrm{C}$, and N. After the post-weld strengthening heat treatment, the base metal microstructure was visually identical to that of the solution-treated metal.

\subsubsection{Weld deposit}

Photographs of the weld before and after final heat treatment are shown with Fig. 4. The weld deposit was characterized by the variations of microstructure normally associated with deposition of successive weld beads. Otherwise, it contained no visible indications of physical defects. However, defects in the cast base metal were visible on these surfaces.

Optical micrographs of the weld deposit before and after final heat treatment are shown in Fig. 5(a) and Fig. 5(b), respectively. A dendritic structure with secondary dendrite arm spacing in the 5-8 $\mu \mathrm{m}$ range was visible before heat treatment. Interdendritic regions etched much darker after heat treatment, presumably related to precipitation in those locations. Welldefined grain boundaries were also visible after heat treatment. The light-etching band in the lower half of Fig. 5(b) is associated with the diffuse boundary between successive weld beads. Heating from deposition of the upper bead would promote a local variation of precipitation and encourage a limited amount of elemental redistribution. Epitaxial growth of grains from the lower bead into the upper one is also visible in Fig. 5(b).

The results from SEM examination of an interdendritic region after the post-weld heat treatment are shown in Fig. 6 , where particles ranging in size from submicron to several microns in largest dimension were found. The EDS chemical mapping results show that many particles have elevated Mo concentrations, including small particles that present as rod
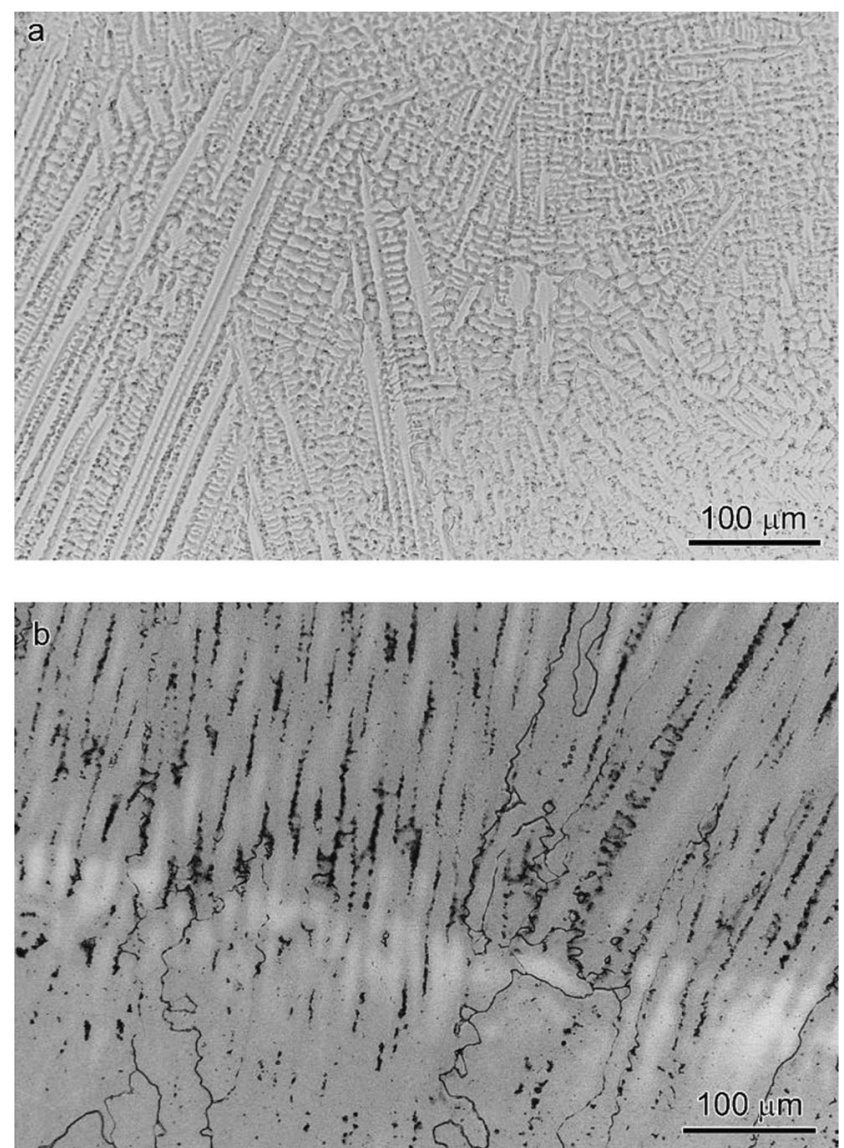

Fig. 5 Optical micrographs of the weld deposit before (a) and after (b) final heat treatment

shapes on this planar surface. A few of the larger particles appear to have the contrast and chemical composition characteristics of the MC phases found throughout the base metal.
Fig. 4 Photographs of fullsection weld deposit (a) aswelded and (b) after post-weld heat treatment. An apparent base metal shrinkage defect is circled in (b)
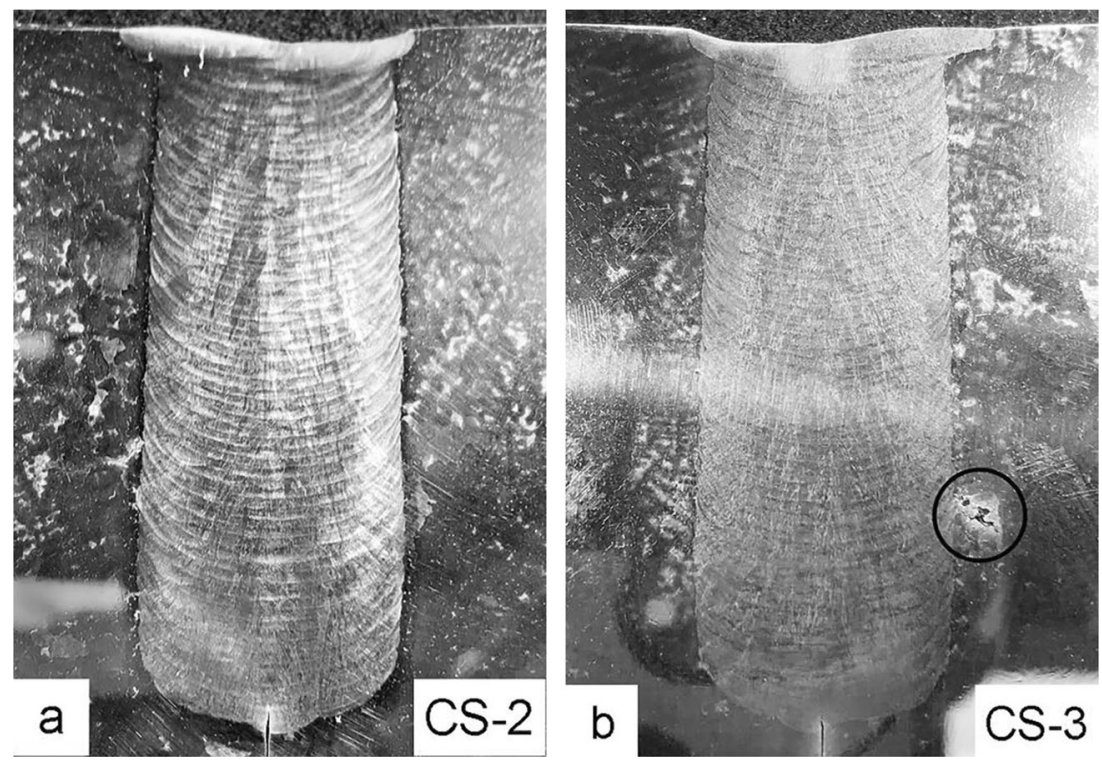
There was also an indication of the presence of small particles enriched in Cr. Small, uniformly distributed spherical particles are the $\gamma^{\prime}$ phase.

The appearance and microstructure of the weld deposit are consistent with other, related work [5] on welding cast Haynes 282. A more recent study [10] showed that weld deposits of repair welds in Haynes 282 are susceptible to solidification cracking. It was suggested that excessive welding heat input and the accumulation of oxides contributed to the cracking, but a definitive cause was not established. No evidence of weld deposit cracking was found in the current weld.

Some details about the solidification behavior of Haynes 282 were analyzed by Bechetti et al. [11] Their work showed that Mo partitions strongly to interdendritic regions, where concentrations of $\mathrm{Cr}$ and $\mathrm{Ti}$ will also be elevated. Analysis of the solidification sequence [11] indicated that intermetallic phases such as $\mu$ and $\sigma$ could also occur in interdendritic regions as solidification ends. The elevated concentrations of Mo and Ti found in an interdendritic location of the weld deposit, Fig. 6, are generally consistent with those predictions.

\subsubsection{Heat-affected zone}

The microstructure of the heat-affected zone of solutiontreated base metal, Fig. 7(a), was characterized by a distinct region of light etching immediately adjacent to the weld fusion line. Because the fusion line establishes a temperature at the solidus, this region, the near heat-affected zone, correlates with metal that experienced excursions up to the base metal solidus during welding. While residence times at the high temperatures would be brief, dissolution of second phases could occur if their solubilities decreased with increasing
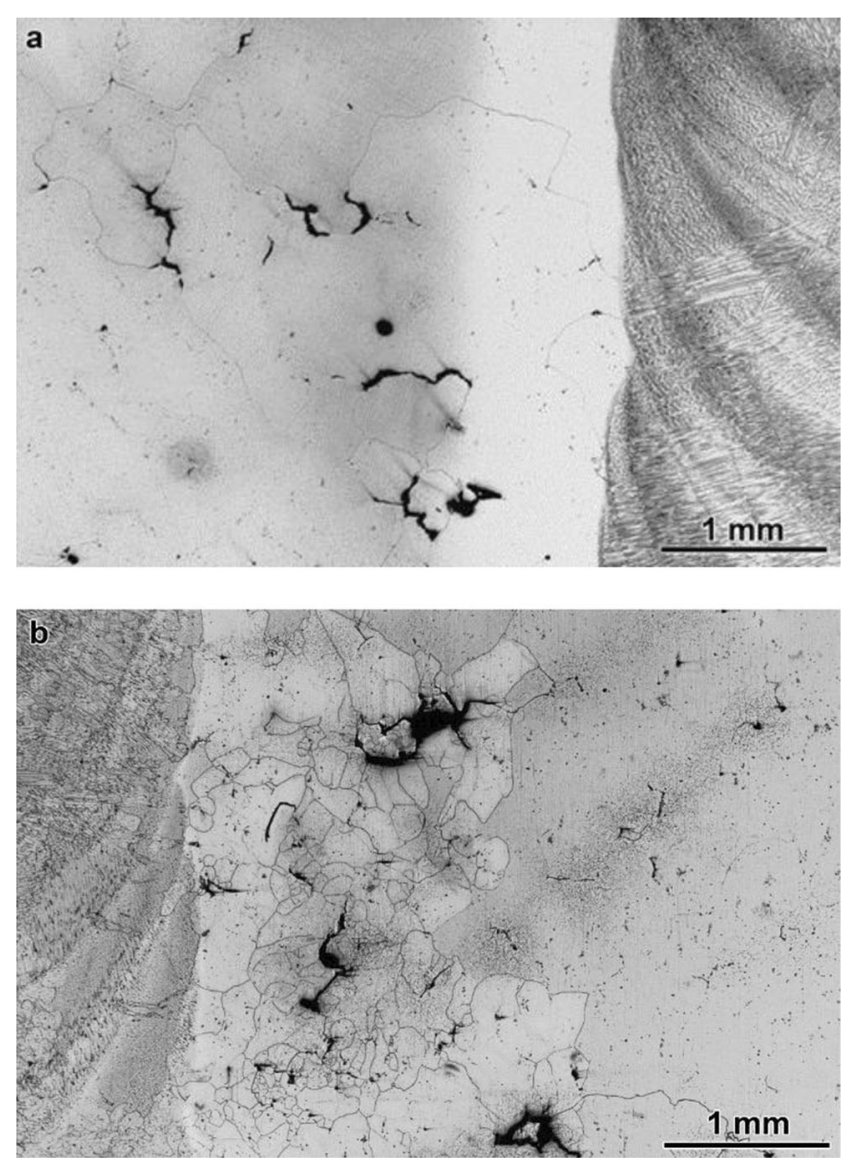

Fig. 7 Optical micrographs showing weld heat-affected zone microstructures of solution-treated base metal (a) and after post-weld strengthening heat treatment (b)
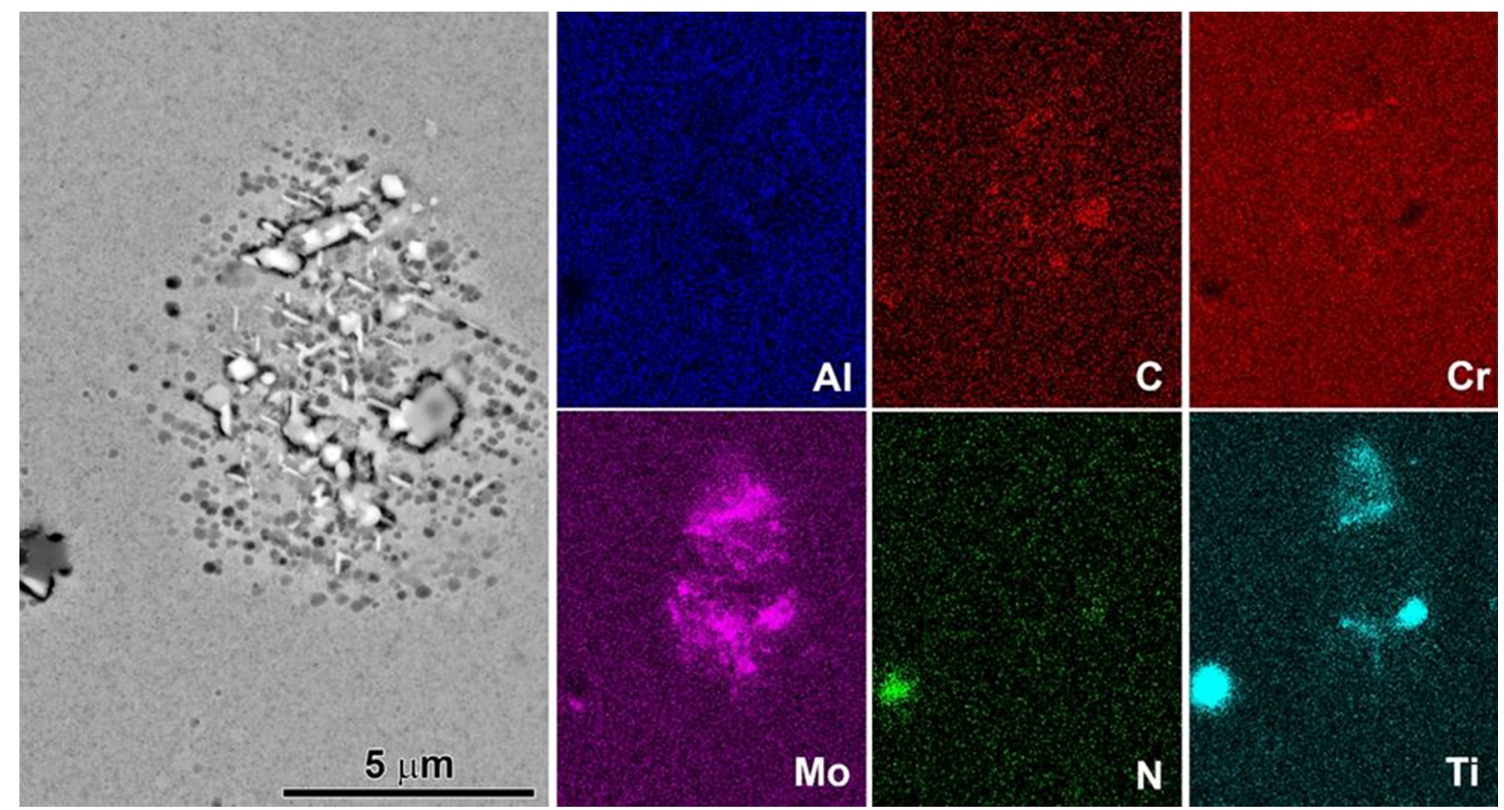

Fig. 6 SEM micrograph from an interdendritic region of weld deposit with corresponding EDS chemical mapping results 
temperature. As distance from the fusion line increases into the base metal, the peak temperatures experienced during welding would decrease. In contrast to regions adjacent to the fusion line, metal further away from the fusion line could actually experience precipitation of second phases when peak temperatures did not exceed solution temperatures. The differences in the response of base metal to the peak temperatures during welding caused the variation in etching response. At the location of Fig. 7(a), there are no indications of significant defects near the fusion line. However, there are many cracks further from the fusion line just beyond the light-etching region in the base metal.

Figure 7(b) shows the microstructure of a similar heataffected zone region after the post-weld strengthening heat treatment. To varying degrees, regions of recrystallization in the near heat-affected zone, like that shown in Fig. 7(b), were distributed around the periphery of the weld. These were typically adjacent to the fusion line. Although some small cracks at this location intersected the fusion line, most did not.

To reiterate, the cast base metal was homogenized and then given its strengthening heat treatment. Before machining of the weld groove details, the cast metal parts were again solution heat treated at $1150{ }^{\circ} \mathrm{C}$ to reduce their hardness. At that stage of heat treatment, it is reasonable to expect that the metal was well annealed and contained a low level of strain energy. After machining of the weld groove detail, the parts were assembled, welded together, and finally given a second strengthening heat treatment. For recrystallization to occur, like that illustrated by Fig. 7(b), an elevated level of strain energy would be required at that location to supply the necessary driving force for nucleation of small new grains. There are two possible sources for causing local deformation and therefore elevated strain energy near the weld deposit. One derives from the localized heating associated with welding. The localized heating is a well-known source of high strains in the vicinity of weld deposits. A second potential source of elevated strain energy near the joint groove is from machining operations. For instance, recrystallization has been used to study the relationships between machining parameters and the depth of surface deformation-induced damage in Ni-base alloys. [12] Presumably, both sources of deformation contributed to the localized recrystallization illustrated with Fig. 7(b). It seems clear that while heating associated with the welding operation would contribute to local deformation, it did not induce recrystallization (Fig. 7(a)). The recrystallization must have initiated during heating to and holding at $1010{ }^{\circ} \mathrm{C}$, the first step of the second strengthening heat treatment.

An example of a microstructural feature found in the heataffected zone is illustrated with Fig. 8 and Fig. 9. The overall shape of this feature in Fig. 8 is similar to the large MC particles found throughout the cast base metal, but instead of being an intact particle, it is a crack surrounded by phases of more complicated appearances. EDS mapping results were inconclusive about the $\mathrm{C}$ distribution around this feature, but

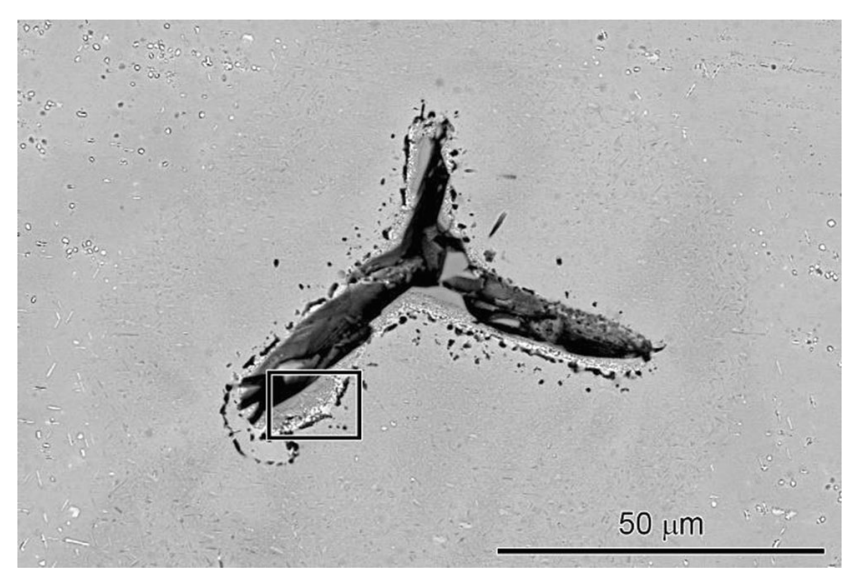

Fig. 8 SEM micrograph of a second-phase particle in the weld heataffected zone. Details in the highlighted area are shown with Fig. 9

spot analyses, Fig. 10, confirmed that locations such as 3 on Fig. 9 were likely the $(\mathrm{Mo}, \mathrm{Ti})(\mathrm{C}, \mathrm{N})$ found throughout the microstructure. The bright contrast features labeled 1 appeared to be individual particles that were primarily elevated in Mo and $\mathrm{Cr}$. This was also confirmed by spot analyses. The region labeled 2 in the image appears composed of more than one phase. It was elevated in $\mathrm{Mo}, \mathrm{Ti}$, and N. Other particles that may be Al-nitride or Al-oxide are also visible. The overall appearance is suggestive of the transformation or reaction of a large MC particle into various product phases.

With regard to cracking phenomena, both strain-age cracking and heat-affected zone cracking are concerns when welding precipitation strengthened alloys like Haynes 282. The resistance of Haynes 282 to strain-age cracking is considered good. [7] On the other hand, the kinetics of the precipitation of $\gamma^{\prime}$ and strengthening carbides during cooling is relatively fast. [13, 14] This means that when solution-treated metal is heated during welding, its strength will likely increase, and its ductility will decrease where temperature excursions are below the $\gamma^{\prime}$ solvus, around $1000^{\circ} \mathrm{C}$. Additionally, large grain size, as is present in this Haynes 282 casting, reduces ductility under simulated welding conditions. [13] Both the rapid precipitation kinetics and large grain size could contribute to a heightened strain-age cracking response.

Considering this rationale, the optical micrograph after welding the solution-treated casting, Fig. 7(a), illustrates a situation that could be associated with strain-age cracking. The heat-affected zone adjacent to the fusion line at this location is free of visible defects. The peak temperatures in this region would have approached the solidus, but cooling rates would also be relatively high. These conditions would not be conducive to significant precipitation of strengthening phases. With increasing distance from the weld fusion line, both the peak temperatures and cooling rates would progressively decrease. In a zone of moderate distance from the fusion line, peak temperatures would be below the $\gamma^{\prime}$ solvus and residence time there could be long enough to promote precipitation. 

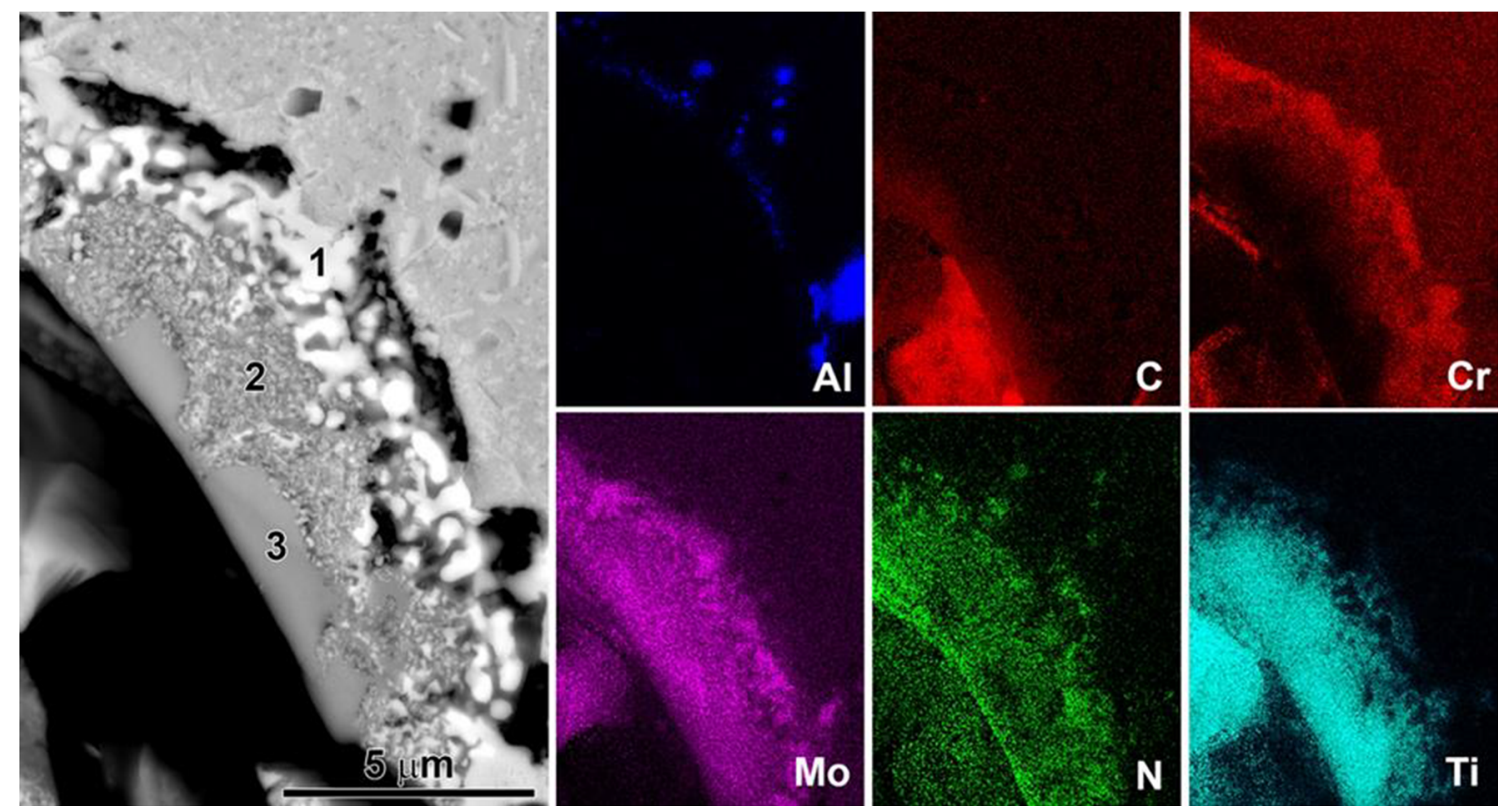

Fig. 9 SEM micrograph of second-phase particle with corresponding EDS chemical mapping results

These regions would be susceptible to strain-age cracking, so the microstructure highlighted by Fig. 7(a) is consistent with this behavior.

In contrast to strain-age cracking, heat-affected zone cracks are typically associated with higher temperature phenomena. These cracks tend to form on grain boundaries that either intersect the fusion line of the weld deposit or are close to it. They are often associated with high-temperature ductility and strength characteristics, or liquation events that produce liquid films along grain boundaries. [15] In evaluating Haynes 282, Andersson et al. [13] concluded that hot ductility of the wrought metal was excellent especially when compared to Waspaloy, another $\gamma^{\prime}$-strengthened alloy that shares the same chemical composition space. Their work also showed that hot ductility was reduced by large grain size. The larger grains were associated with an increased tendency for liquation along grain boundaries during short-time, high-temperature excursions experienced during welding. The liquation was attributed to eutectic formation that correlated with reductions in ductility and strength. A similar study $[16,17]$ on wrought Haynes 282 found that reduced high-temperature ductility correlated with the liquation of boride particles on grain boundaries. The effect of the particles on reducing ductility was magnified with increased grain size.

Rapid dissolution of borides and carbides on grain boundaries is a plausible source of liquation in Haynes 282. This can be visualized with Fig. 11 where predictions of thermodynamic equilibrium are plotted to highlight the $\mathrm{M}_{3} \mathrm{~B}_{2}$ and $\mathrm{MC}$ phases. Below the $1261{ }^{\circ} \mathrm{C}$ solidus, the amount of $\mathrm{M}_{3} \mathrm{~B}_{2}$ continuously increases with decreasing temperature.

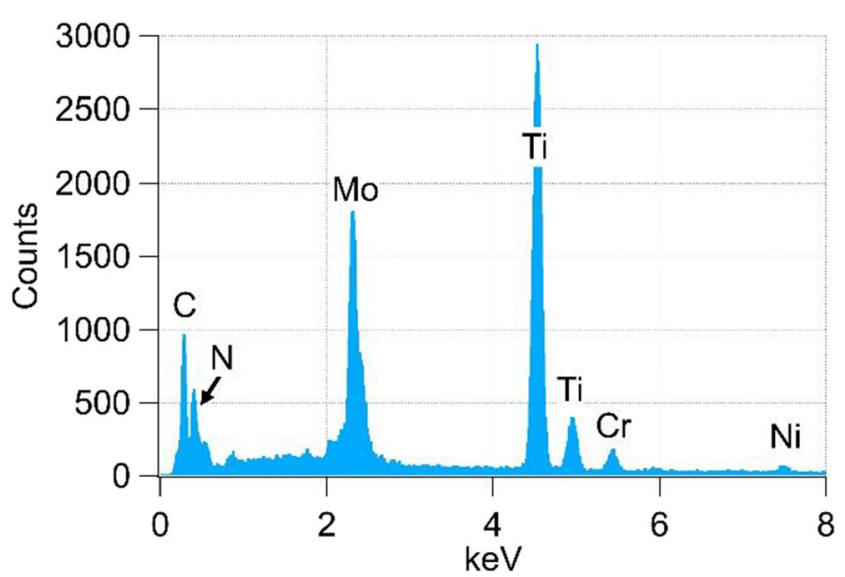

Fig. 10 EDS spectrum showing major elements from the spot chemical analysis of location 3 in Fig. 9

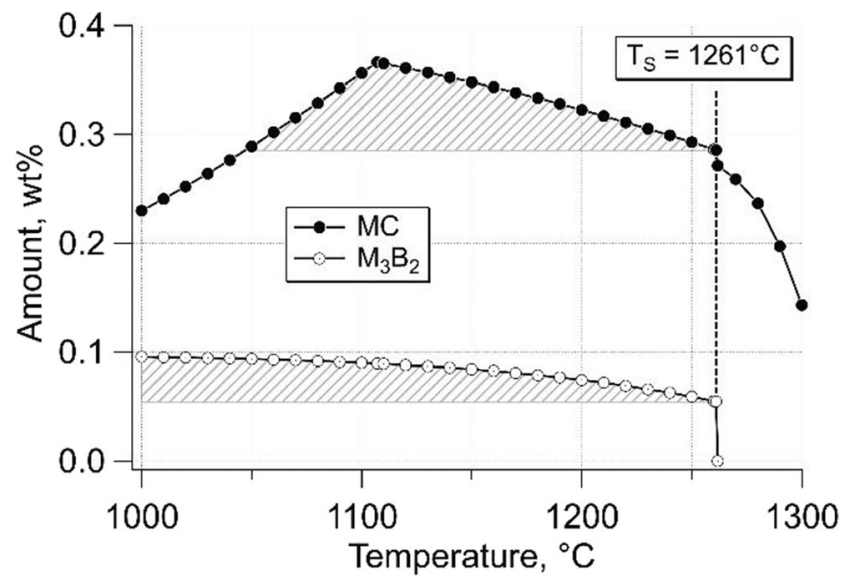

Fig. 11 Calculated variations of the equilibrium amounts of $\mathrm{MC}$ and $\mathrm{M}_{3} \mathrm{~B}_{2}$ phases 
Consequently, metal that experienced a sequence of heat treatments below the solidus would likely contain an amount of $\mathrm{M}_{3} \mathrm{~B}_{2}$ higher than the amount stable at the solidus. When metal with the higher amount of $\mathrm{M}_{3} \mathrm{~B}_{2}$ was heated to the solidus during welding, for instance, any amount of $\mathrm{M}_{3} \mathrm{~B}_{2}$ in excess of what exists at the solidus would begin rapidly dissolving. The cross-hatched region in Fig. 11 represents the possible range of excess amounts relative to the amount stable at the solidus. The dissolution of any excess amounts of $M_{3} B_{2}$ that exist on grain boundaries would increase the local concentrations of dissolved B which is a powerful melting-point depressant in $\mathrm{Ni}$. A result of this is the likely formation of liquid films at temperatures below the bulk alloy solidus and an increased tendency for heat-affected zone cracking. A similar situation exists for MC phase although its behavior is somewhat more complicated because of the formation of $\mathrm{M}_{6} \mathrm{C}$ below about $1110{ }^{\circ} \mathrm{C}$. Rapid dissolution of $\mathrm{MC}$ could cause locally elevated concentrations of dissolved $\mathrm{Ti}$, another powerful melting-point depressant in $\mathrm{Ni}$.

Other welding studies of Haynes 282 show that both wrought and cast metal can exhibit heat-affected zone cracking. $[5,17]$ The cracking of laser-welded wrought metal was associated with liquation of boride particles [16] that were subsequently identified as $\mathrm{Mo}_{5} \mathrm{~B}_{3}$. [18]

Often the probable source of heat-affected zone cracking can be established by metallographic examinations. Many of the heat-affected zone cracks like shown in Fig. 7 either intersected the fusion boundary between base metal and weld metal or were close to it. It was not possible to determine unequivocally that any phases indicative of liquation occurred at these crack surfaces. On the other hand, cracks like that shown as Fig. 8 were found at various locations in the heataffected zone. The evidence from Figs. 8 and 9 suggests that this crack could have resulted from liquation of a large $\mathrm{MC}$ particle and that reactions with nearby particles contributed to the event. Based on the foregoing discussion, it seems prudent to be concerned about heat-affected zone cracking in cast Haynes 282, but firmly establishing tendencies for it will require a more focused, detailed study.

\subsection{Properties}

\subsubsection{Hardness testing}

Vickers microhardness testing on lightly etched specimens with an indenter load of $200 \mathrm{~g}$ was used for an initial assessment of the weldment properties. The hardness indents were automatically arranged in 4-mm $\times 8-\mathrm{mm}$ arrays with spacing of $200 \mu \mathrm{m}$. This produced 861 total indents. Indent measurement was also done automatically. The arrays were positioned so that the 8 -mm array length was approximately perpendicular to the weld-metal/base-metal interface with about $4 \mathrm{~mm}$ of length on either side of it.
The hardness results are plotted in Fig. 12 as linear transits across weld metal, heat-affected zone, and base metal. Because the arrays are composed of stacks of 21 transits, they were averaged to illustrate the scatter. The approximate location of the fusion boundary is indicated on each plot. Average hardness values were determined using the leftmost $5 \times 21$ indent arrays for the weld deposit and the rightmost ones for base metal. In the as-welded condition, the weld deposit hardness is $341 \pm 16$, and the base metal hardness is $355 \pm 10$. Using a $3 \times 21$ array, the hardness was estimated as $321 \pm 26$ in the narrow, light-etching region in the base metal adjacent to the fusion boundary. After the post-weld heat treatment, the base metal experienced a moderate hardness increase up to an average value of $370 \pm 13$. In contrast, heat treatment increased the hardness of the weld deposit to $399 \pm 12$. The hardness of the near heat-affected zone adjacent to the fusion boundary was increased to $367 \pm 18$, just slightly below the average base metal value.

Figure 12 confirms that a region of slightly depressed hardness persisted adjacent to the fusion boundary after the heat
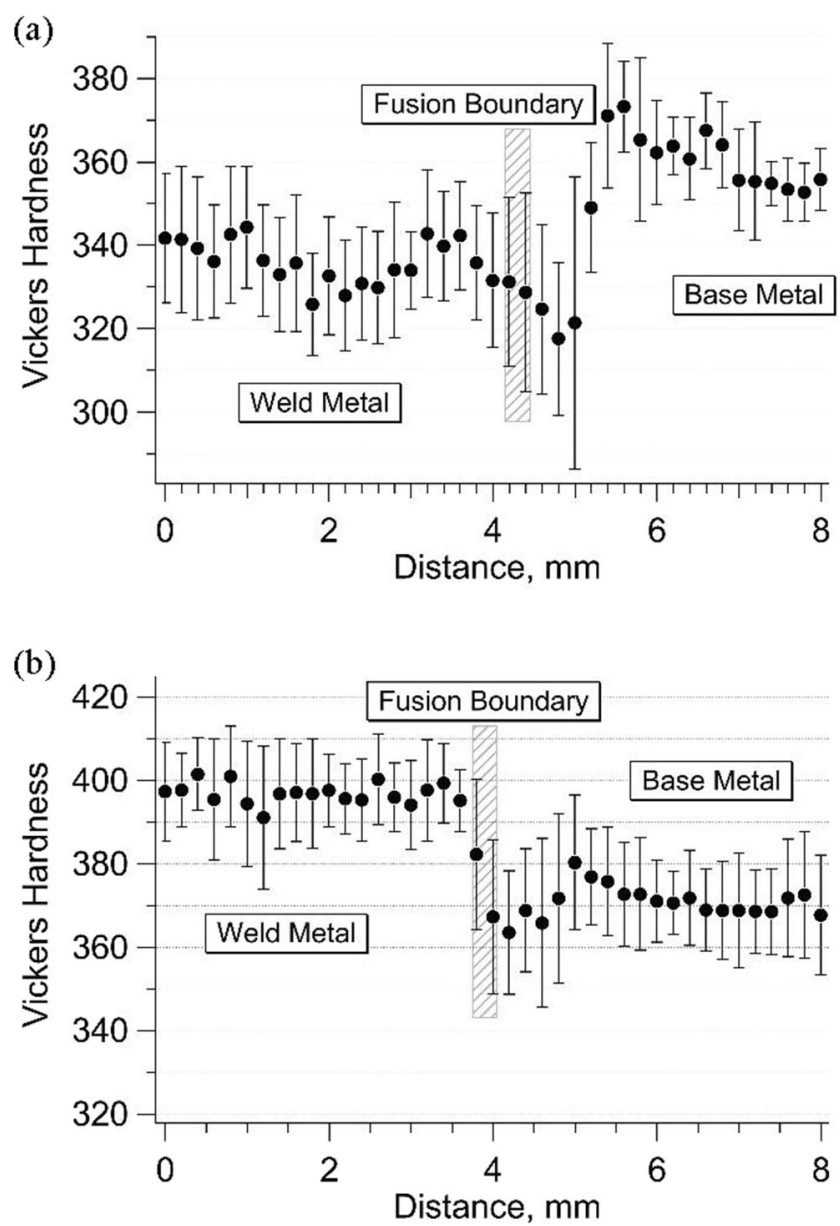

Fig. 12 Hardness traverse plots for as-weld condition (a) and after postweld heat treatment (b). Cross-hatching shows fusion boundary locations on each plot 
treatment. Before welding, the base metal was solution treated at $1150{ }^{\circ} \mathrm{C}$, a temperature high enough to dissolve $\gamma^{\prime}$ strengthening precipitates. However, the cooling rate after solution treatment was in the range of several ${ }^{\circ} \mathrm{C} / \mathrm{min}$, slow enough for some reprecipitation of $\gamma^{\prime}$ to occur. [14] In comparison, temperatures due to local heating from welding would have approached the solidus, around $1261{ }^{\circ} \mathrm{C}$, with cooling at a relatively high rate, perhaps on the order of $100{ }^{\circ} \mathrm{C} / \mathrm{min}$. From this, it is plausible that reprecipitation of $\gamma^{\prime}$ in the near heat-affected zone was suppressed relative to what might occur when cooling from solution treatment. This scenario is consistent with reduced hardness in the near heat-affected zone as Fig. 12 shows. The slight increase of hardness in the base metal beyond this softer zone is also confirmed. This behavior is consistent with a strain aging response as previously suggested.

The hardness increase in the weld deposit compared to the base metal after post-weld heat treatment could be caused by its higher $\mathrm{Al}$ concentration and lower concentration of $\mathrm{C}$ (Table 1). The higher $\mathrm{Al}$ concentration in the weld deposit would slightly increase the amount of $\gamma^{\prime}$. The lower $\mathrm{C}$ concentration, for instance, would reduce the amount of Ti precipitating in Ti-rich MC phases. This would permit more Ti to participate in forming $\gamma^{\prime}$. The microstructure observations are consistent with the weld deposit having a lower amount of MC phases compared to the base metal.

Figure 12(b) indicates that hardness gradients in the heataffected zone were nearly eliminated by the post-weld strengthening heat treatment. These figures also indicate there is no clear effect of local recrystallization, Fig. 7(b), on the hardness.

\subsubsection{Tensile testing}

The results from tensile testing of cross-weld specimens are tabulated in Table 2 . The variation of tensile strength with test temperature is shown with Fig. 13 where the cross-weld results are compared to those from base metal specimens taken from elsewhere in the main body of the original $7,700 \mathrm{~kg}$ casting. [5] Over the temperature range shown in Fig. 13,

Table 2 Tensile test results for cross-weld specimens

\begin{tabular}{llllll}
\hline ID & T, ${ }^{\circ} \mathrm{C}$ & UTS, MPa & TE, \% & ROA, \% & Failure \\
\hline SB18 & 22 & 550 & 0.5 & -- & Base \\
SB28 & 371 & 474 & 0.23 & -- & Base \\
SB7 & 704 & 510 & 1.03 & -- & Base \\
SB9 & 760 & 507 & 1.15 & --- & Base \\
SB12 & 816 & 468 & 2.2 & 2.8 & Base \\
\hline
\end{tabular}

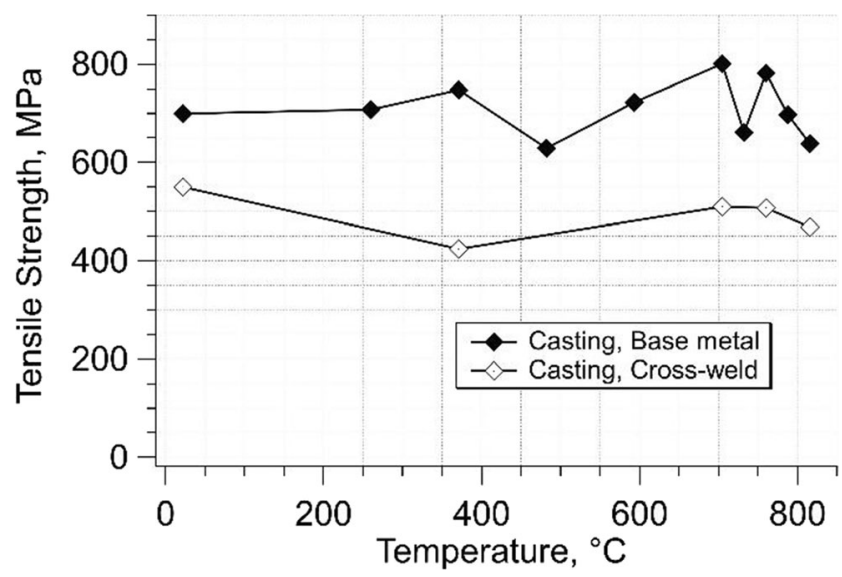

Fig. 13 Comparison of tensile strength for base metals and cross-weld test specimens

the cross-weld strength values were in the range of 57-79\% of the base metal values. Failures of the cross-weld specimens occurred in the cast base metal. None of the test specimens failed in the weld deposit.

The distribution of preexisting defects in the cast base metal is one factor that could have contributed to the lower strength of the cross-weld specimens. No effort was made to specifically characterize the overall defect condition of the original large casting, but there is no reason to expect that defects were uniformly distributed. For instance, the cross-weld slice shown as Fig. 2 contained the largest and largest number of casting defects of the 6 slices machined from the completed weld. In contrast to the observations of the slices, no defect indications were found by dye-penetrant inspection of some of the machined cross-weld specimens. It is plausible that the location used to provide stock for making this weld, near a riser, contained a higher concentration of casting defects than other locations in the main body of the casting. Such variations in the distribution of casting defects would have influenced strength values.

Because of the large number of preexisting defects in the base metal, it was not possible to determine unambiguously that welding increased the number of defects in the base metal, by heat-affected zone liquation cracking or strain-age cracking, for instance. However, it seems likely that strains imposed on the metal during welding could have caused preexisting shrinkage cracks to enlarge. If this occurred, it could also contribute to reduced tensile strength.

The low ductility values in the cross-weld specimens could have resulted not only from casting defects and large grain size, but by the distribution of large second-phase particles on grain boundaries as well.

Lastly, there is no indication from tensile testing that the weld deposit represented a weak link in the crossweld strength. 


\subsubsection{Stress-rupture testing}

The results from stress-rupture testing of cross-weld specimens are tabulated in Table 3. The variation of applied stress with Larson-Miller parameter for the cross-weld specimens is shown in Fig. 14, where results from testing wrought base metal $[5,19,20]$ and cross-weld specimens of wrought base metal [21] are shown for comparison. The bracketed values for life in Table 3 and the open symbols in Fig. 14 indicate ongoing tests.

Just as for the tensile tests, the failure locations of the crossweld specimens were in the cast base metal. This suggests that the rupture strength of the weld deposit exceeded that of the cast base metal and that the intrinsic strength of the base metal controlled failure. It further suggests that heat-affected zone microcracking and localized recrystallization had no significant effect on cross-weld rupture strength. Figure 14 also shows that the rupture strengths of cross-weld specimens as well as cast base metal specimens were within $80 \%$ of the rupture strength of wrought base metal reference results. Also, there was no significant difference in cross-weld rupture strengths for the cast base metal and wrought base metal.

Considering the condition of the cast base metal with regard to casting defects and possible weld microcracking, its performance in stress-rupture testing is encouraging. In terms of precipitation, the microstructure of the wrought base metal is considered optimized for creep strength. [6, 7, 22] Besides uniform dispersions of $\gamma^{\prime}$ and carbides, large grain size can also benefit performance in creep conditions. [23] The state of the cast base metal relative to precipitation of $\gamma^{\prime}$ is not well characterized, but its large grains would tend to give it an advantage in creep loading over wrought metal with smaller grain size. This advantage of larger grains derives from the reduced number of grain boundary triple points where nucleation of creep cracks is favored. However, any grain size advantage of the cast base metal would be offset to some extent by the presence of defects and microcracking that would

Table 3 Stress-rupture data for cross-weld specimens

\begin{tabular}{lllllll}
\hline ID & Test & Stress, MPa & T, ${ }^{\circ} \mathrm{C}$ & Life, $\mathrm{h}$ & Elong., \% & ROA, \% \\
\hline SB2 & 33611 & 336 & 704 & 1744.4 & 4.0 & 41.6 \\
SB5 & 33838 & 324 & 704 & 6118 & 4.9 & 29.8 \\
SB3 & 33489 & 256 & 760 & 2454.6 & 4.2 & 37.7 \\
SB13 & 33836 & 198 & 760 & 6470 & 5.2 & 8.8 \\
SB6 & 33612 & 136 & 816 & 3218.2 & 3.5 & 5.9 \\
SB4 & 34759 & 303 & 704 & {$[10469.4]^{1}$} & --- & --- \\
SB14 & 34758 & 179 & 760 & {$[10469.4]^{1}$} & --- & --- \\
SB26 & 38361 & 110 & 816 & {$[7685.4]^{1}$} & --- & --- \\
SB15 & 33837 & 90 & 816 & {$[18646.8]^{1}$} & --- & --- \\
\hline
\end{tabular}

${ }^{1}$ Ongoing test as of Jan 4, 2021

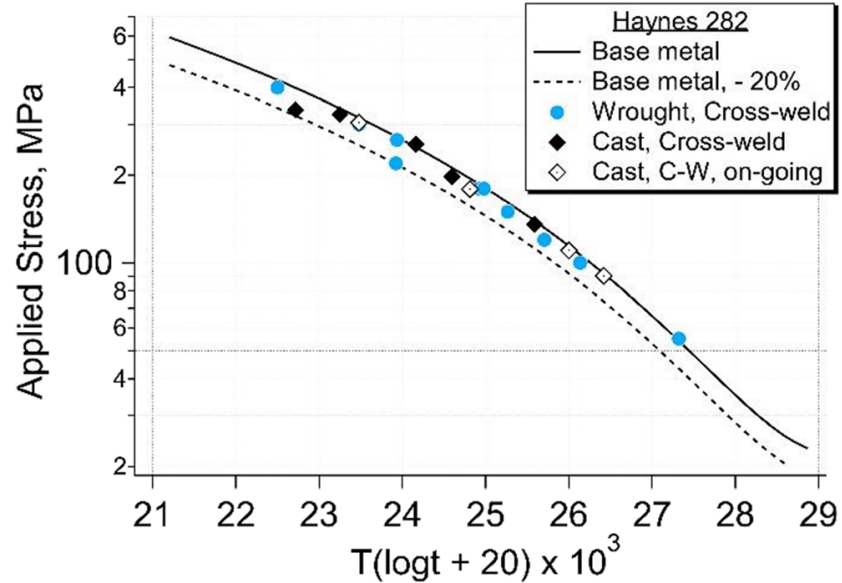

Fig. 14 Variation of applied stress with Larson-Miller parameter for cross-weld stress-rupture results. Open symbols represent ongoing tests

eliminate the time needed for crack nucleation in creep loading conditions.

Another potential advantage of the cast base metal is the distribution of large carbides along its grain boundaries. There are many carbides with major dimension $\geq 50 \mu \mathrm{m}$ on grain boundaries. As well as much smaller, uniformly distributed carbides, ones in this large size range can benefit creep properties. [24] In any event, it is clear that the presence of defects in the cast base metal did not significantly decrease its rupture strength or that of cross-weld test specimens compared to those of wrought base metal. These results also suggest that the intrinsic strength of the cast base metal may be high enough to offset any effects of heat-affected zone issues in tests of cross-weld specimens.

\section{Summary}

A 50.8-mm-deep, narrow-gap, gas tungsten arc weld was made in a semi-circular ring section of a Haynes 282 casting. The weld was completed with a total of 104 weld beads. No cracking was observed in the weld deposit during the processing.

The weld heat-affected zone microstructure was characterized by microcracking and localized recrystallization. Direct evidence of the likely source of the microcracking could not be identified. Localized recrystallization in the base metal near the weld fusion line was found only after the post-weld strengthening heat treatment.

In the as-welded condition, average Vickers hardness values were $341 \pm 16$ in the weld deposit, $355 \pm 10$ in the base metal, and $321 \pm 26$ in a narrow, light-etching region immediately adjacent to the weld fusion line in the heat-affected zone. After the strengthening heat treatment, the respective hardness values were $370 \pm 13,399 \pm 12$, and $367 \pm 18$. 
The results from tensile testing of cross-weld specimens up to $816{ }^{\circ} \mathrm{C}$ showed that their strengths ranged from 57 to $79 \%$ of the cast base metal tensile strength. Failure locations were in base metal rather than the weld deposit.

The stress-rupture strengths of cross-weld specimens are within $20 \%$ or less of base metal reference data. Failed cross-weld stress-rupture specimens also broke in the base metal.

Acknowledgements This research was sponsored at the Oak Ridge National Laboratory by the U.S. Department of Energy, Office of Fossil Energy, under Contract DE-AC05-00OR22725 with UT Battelle, LLC. Significant contributions to this work were made by Alan Frederick, Tom Geer, Doug Kyle, Tracie Lowe, and Jeremy Moser. Their support was critical to coordinating and completing numerous technical activities, testing, and analyses. Technical discussions with Michael Haines of University of Tennessee were appreciated. Wei Tang and Peter Tortorelli reviewed the manuscript for technical content and provided many thoughtful comments.

Open Access This article is licensed under a Creative Commons Attribution 4.0 International License, which permits use, sharing, adaptation, distribution and reproduction in any medium or format, as long as you give appropriate credit to the original author(s) and the source, provide a link to the Creative Commons licence, and indicate if changes were made. The images or other third party material in this article are included in the article's Creative Commons licence, unless indicated otherwise in a credit line to the material. If material is not included in the article's Creative Commons licence and your intended use is not permitted by statutory regulation or exceeds the permitted use, you will need to obtain permission directly from the copyright holder. To view a copy of this licence, visit http://creativecommons.org/licenses/by/4.0/.

\section{References}

1. Viswanathan R, Bakker W (2001) Materials for ultrasupercritical coal power plants - turbine materials: part II. J Mater Eng Perform 10:96-101

2. Viswanathan R, Henry RF, Tanzosh J, Stanko JG, Shingledecker J, Vitalis B, Purgert R (2005) U.S. program on materials technology for ultra-supercritical coal power plants. J Mater Eng Perform 14: 281-292

3. Viswanathan R, Bakker W (2001) Materials for ultrasupercritical coal power plants - boiler materials: part 1. J Mater Eng Perform 10:81-95

4. Purgert R, Shingledecker J, Ganta R, Pschirer J, Weitzel P, Sarver J, Vitalis B, Gagliano M, Stanko G, Tortorelli P (2015) Boiler materials for ultra supercritical coal power plants, final technical report. DOI 10:2172-1346714

5. Purgert R, Shingledecker J, Saha D, Thangirala M, Booras G, Powers J, Riley C, Hendrix H (2015) Materials for advanced ultrasupercritical steam turbines, final technical report. DOI 10: 2172-1243058

6. Pike LM and Flower HL (2006) Gas turbine superalloy with improved fabricability. Adv Mater Process pp 39-42

7. Pike LM (2008) Development of a fabricable gamma-prime $\left(\gamma^{\prime}\right)$ strengthened superalloy. In: Reed RC, Green KA, Caron P, Gabb TP, Fahrmann MG, Huron ES, and Woodard SA (eds) Superalloys 2008, TMS, pp 191-200
8. Jablonski PD, Hawk JA, Cowan CJ, Maziasz PJ (2012) Processing of advanced cast alloys for A-USC steam turbine applications. JOM 64:271-279

9. Santella M, Chen XF, Rausch J, Salkin J, and Maziasz P (2020) Microstructure and strength of a thick-section gas-tungsten-arc weld in cast Haynes ${ }^{\circledR} 282$ alloy. doi:https://doi.org/10.2172/ 1671411. https://www.osti.gov/servlets/purl/1671411

10. Hanning F, Andersson J (2018) Weldability of wrought Haynes® $282 \circledR$ repair welded using manual gas tungsten arc welding. Weld World 62:39-45

11. Bechetti DH, DuPont JN, Siefert JA, Shingledecker JP (2016) Microstructural evolution and creep-rupture behavior of A-USC alloy fusion welds. Metall Mater Trans A 47A:4502-4518

12. Chen $Y$, Bunget $C$, Mears L, Kurfess TR (2016) Investigations in subsurface damage when machining $\gamma^{\prime}$-strengthened nickel-based superalloy. Proc IMechE Part B: J Eng Manufacture 230(7):12211233

13. Andersson J, Sjöberg G, and Chaturvedi M (2010) Hot ductility study of HAYNES® $282 \AA$ superalloy. In: Ott EA, Groh JR, Banik A, Dempster I, Gabb TP, Helmink R, Liu X, Mitchell A, Sjörberg GP, and Wusatowska-Sarnek A (eds) 7th International Symposium on Superalloy 718 and Derivatives, TMS, pp 539-554

14. Fahrmann MG, Metzler DA (2016) Simulation of $\gamma^{\prime}$ precipitation kinetics in a commercial Ni-base superalloy. JOM 68:2786-2792. https://doi.org/10.1007/s11837-016-2097-5

15. DuPont JN, Lippold JC, Kiser SD (2009) Welding metallurgy and weldability of nickel-base alloys. Wiley, Hoboken, New Jersey, pp 223-235

16. Osoba LO, Ding RG, Ojo OA (2012) Improved resistance to laser weld heat-affected zone microfissuring in a newly developed superalloy HAYNES 282. Metall Mater Trans A 43A:4281-4295

17. Osoba LO, Ojo OA (2012) Influence of laser welding heat input on HAZ cracking in newly developed Haynes 282 superalloy. Mater Sci Technol 28:431-436

18. Osoba LO, Khan AK, Ojo OA (2017) Identification of Mo-based precipitates in Haynes 282 Superalloy. Metall Mater Trans A 48A: $1540-1543$

19. Haynes ${ }^{\circledR} 282 \circledR$ alloy (2017) Haynes International, H-3173B, https://haynesintl.com

20. Kim Y-J, Park J-H, Ahn Y-S (2018) Comparison of creep properties of cast and wrought Haynes 282 superalloy. Adv Mater Sci Eng Article ID 2048959. https://doi.org/10.1155/2018/2048959

21. Maziasz PJ, Moser J, Unocic K, Yang Y, Purdy D, Jablonski PD (2016) Tensile, creep and microstructural behavior of welded cast Haynes 282 alloy for A-USC steam turbine casing applications. In: Parker J, Shingledecker J, Siefert J (eds) Advances in materials technology for fossil power plants, Proceedings from the Eighth International Conference, October 11-14, 2016, Albufeira, Algarve, Portugal, ASM International ${ }^{\circledR}$. Ohio, Materials Park, pp 703-714

22. Klarstrom DL, Pike LM, Ishwar VR (2013) Nickel-base alloy solutions for ultrasupercritical steam power plants. Procedia Eng 55: 221-225

23. Liu CD, Han YF, Yan MG, and Chaturvedi MC (1991) Creep crack growth behavior of alloy 718. In: Loria EA (ed) Superalloys 718, 625 , and various derivatives, The Minerals, Metals, and Materials Society, pp 537-548

24. Rösler J, Evans AG (1992) The effect of reinforcement size on the creep strength of intermetallic matrix composites. Mater Sci Eng A153:438-443

Publisher's note Springer Nature remains neutral with regard to jurisdictional claims in published maps and institutional affiliations. 